\title{
Fish blood as a chemical signal for Antarctic marine invertebrates
}

\author{
Anna Kidawa $\cdot$ Katarzyna Stepanowska $\cdot$ \\ Marta Markowska $\cdot$ Stanisław Rakusa-Suszczewski
}

Received: 15 November 2006 / Revised: 8 October 2007 / Accepted: 8 October 2007 / Published online: 24 October 2007

(C) Springer-Verlag 2007

\begin{abstract}
Chemical cues released from dead or injured organisms constitute important signals informing nearby animals about a feeding possibility. The ability to detect the signal, evaluate its meaning and locate its source can help organisms to exploit food resources efficiently, which is especially important to animals living in environments with limited food supply. Experiments were carried out to study the behavioral responses of several Antarctic benthic invertebrates to fish (Notothenia corriceps) blood. Necrophagous species such as sea stars Odontaster validus and Lysasterias sp., amphipod Waldeckia obesa and nemertean Parborlasia corrugatus responded to fish blood with changes in their behavior. The behavior common to all these species was locomotion directed towards the stimulus source. Behavioral components consistent with food consumption were observed in $O$. validus and $P$. corrugatus. The reaction of herbivorous limpets Nacella concinna to fish blood depended on the animal size. Large $(>10 \mathrm{~mm})$ limpets showed no behavioral response, whereas small ones $(<10 \mathrm{~mm})$ reacted to the stimulus by moving a short distance away. These results indicate that blood released from the tissues of injured or dead animals may be an important chemical signal for organisms belonging to different taxa.
\end{abstract}

\footnotetext{
A. Kidawa $(\square) \cdot$ M. Markowska $\cdot$ S. Rakusa-Suszczewski

Department of Antarctic Biology,

Polish Academy of Sciences, ul. Ustrzycka 10/12,

02-141 Warsaw, Poland

e-mail: anna_kidawa@wp.pl

\section{K. Stepanowska}

Department of Biological of Marine Resources,

Faculty of Food Sciences and Fisheries,

University of Agriculture in Szczecin,

ul. Kazimierza Królewicza 4, 71-550 Szczecin, Poland
}

\section{Introduction}

Chemoreception plays an important role in the life of many marine and freshwater species, enabling them to locate conspecifics, favorable microhabitats or food, and providing them information about predators or competitors (e.g., reviewed in Zimmer and Butman 2000). The Southern Ocean is characterized by a combination of low but stable temperatures and intense seasonality of food (Clarke 1983, 1988). Most of the primary production in the Antarctic is limited to a few months during the austral summer (Clarke and Leakey 1996). For the remaining part of the year, pelagic food items (e.g., dead zooplankton) do not reach benthic communities, and consequently these organisms are food limited for considerable periods of time (Clarke 1983; Arnaud 1970). Food resources accessible to necrophagous species during this time of the year (carrion, seal feces, discarded prey remains) are probably unpredictable in space and time, making scavenging opportunities relatively rare and causing periodic intensification of both intra- and interspecific competition (Arnaud 1970). Blood, easily freed from freshly killed or injured prey, may be a potential important signal of a predation event. Such information is especially relevant for necrophagous animals, kleptoparasites or potential prey. The ability to utilize blood signals as a means of locating such unpredictable food sources (or avoiding places where predators aggregate) may considerably increase the organism's prospects of survival in the harsh Antarctic environment. Partial predation, resulting in the release of blood and other body fluids, has been documented in a variety of predator-prey situations, including predation of gastropods by crabs (Dudgeon and Cheung 1990), scallops by crabs (Jørgensen 2005), cropping of clam siphons by fish (Peterson and Skilleter 1994) and predation of polychaete segments by other predatory polychaetes 
(Zajac 1995). In consequence, scraps of partially eaten prey were left uneaten and can be exploited by other predators or scavengers.

The aim of the present paper was to investigate the impact of fish blood released into the environment on the behavior of a suite of ecologically important necrophagous benthic macroinvertebrates. Four necrophagous (sea stars Odontaster validus and Lysasterias sp., amphipod Waldeckia obesa and nemertean Parborlasia corrugatus) and one potential prey species (limpet Nacella concinna) were chosen as test animals. A hypothesis that small limpets, being more susceptible to predation, will react to a potential predation event (fish blood) more strongly than large ones was also tested.

All tested necrophagous species have circum-Antarctic distribution and are common in benthic environments (Dearborn 1977; McClintock et al. 1988; Heine et al. 1991; Graeve et al. 2001). Sea star O. validus Koehler is omnivorous, acting as a scavenger, an active predator, a herbivore or a suspension feeder (Dearborn 1977; McClintock 1994). W. obesa (Chevreux, 1905) is a large scavenging amphipod, feeding on fish and invertebrate carcasses (Arnaud 1970; Graeve et al. 2001). Sea star Lysasterias sp. (Studer) is an omnivorous species, acting as a scavenger or an active predator (Dearborn 1977; Presler 1986). Huge nemertean $P$. corrugatus is a scavenging and predatory species, excreting mucus containing cytolytic toxins (Heine et al. 1991; Berne et al. 2003).

The Antarctic limpet $N$. concinna (Strebel, 1908) occurs on rocky bottoms along the Antarctic Peninsula and adjacent islands (Picken 1980). It is herbivorous and feeds on benthic microalgae (Davenport 1997). N. concinna is preyed upon by predatory sea stars such as Neosmilaster georgianus (Dearborn 1977; McClintock 1994).

\section{Materials and methods}

The common benthic Antarctic fish Notothenia corriceps was caught in Admiralty Bay in the area of Thomas PointShag Point in January (fish 1) and February (fish 2) 2005 in the gill-nets (mesh size $50 \mathrm{~mm}$ ) from a depth of 10-30 m. Blood samples were collected from caudal vessels, then cooled and centrifuged at 3,500 U/min. The serum obtained was stored in polypropylene vials at $-24^{\circ} \mathrm{C}$ until the assays.

The blood serum was assayed for:

- Crude protein: biuret method, with a POCH Gliwice diagnostic kit

- Glucose: enzymatically, with a BioMerieux diagnostic kit

- Triacyloglicerols: enzymatically, with a BioMerieux diagnostic kit
- Total cholesterol and its high-density lipoprotein fraction (HDL-cholesterol): enzymatically, with a BioMerieux diagnostic kit, by spectrophotometer.

Each assay was replicated five times. Average concentrations of measured blood components (Table 1) were typical for $N$. corriceps at this time of the year (Stepanowska in prep.).

All experimental species were either collected by Scuba divers (O. validus, Lysasterias sp., N. concinna, P. corrugatus) or caught in baited traps (W. obesa) in December 2004 from Admiralty Bay (King George Island, South Shetlands, Antarctica). They were maintained in wellaerated tanks at a temperature of $0.0^{\circ} \mathrm{C}$ and water salinity of 34.2-34.5 psu. $O$. validus, Lysasterias sp., W. obesa and $P$. corrugatus were fed Notothenia sp. muscle to minimize differences in their feeding status and then starved (30 days for sea stars, 14 days for $W$. obesa and P. corrugatus). Experiments on $N$. concinna were carried out $24 \mathrm{~h}$ after their collection. No individual was tested more than once in 3 days and no animal was used for the same test stimulus more than once. Each variant of the experiment was replicated 20 times, except $P$. corrugatus (only three specimens of this species were collected). Pure ambient seawater was used as control. Blood stimulus was prepared by mixing fish blood with seawater in the proportion of 1:3. After each repetition of the experiment, the aquariums were thoroughly and repeatedly rinsed with pure seawater to avoid contamination by blood from the previous tests.

Specimen of $O$. validus $(R=3.3-3.6 \mathrm{~cm})$ and Lysasterias sp. $(R=7.3-8.5 \mathrm{~cm})$ were placed individually in 2-1 tanks with static water, and left there for $1 \mathrm{~h}$ to allow them to recover from handling stress. After that time, the animals were found immobile on the tank wall, with one or more arms extended parallel to the air-water interface. No tube foot waving was observed in undisturbed individuals prior to the tests. The behavioral response of both $O$. validus and Lysasterias sp. was measured by releasing $1 \mathrm{ml}$ of potential stimulus from a syringe kept about $3 \mathrm{~cm}$ from the tip of the sea star arm. Animals were then observed for $20 \mathrm{~min}$ and their response was recorded. Behavioral responses were

Table 1 Contents of the chosen components of $N$. corriceps blood serum $($ mean $\pm \mathrm{SD})$

\begin{tabular}{lcc}
\hline $\begin{array}{l}\text { Blood components } \\
\left(\mathrm{mg} \mathrm{dl}^{-1}\right)\end{array}$ & $\begin{array}{l}\text { Fish 1 } \\
(\text { female, 1,040 g w.w.) }\end{array}$ & $\begin{array}{l}\text { Fish 2 } \\
\text { (female, 1,440 g w.w.) }\end{array}$ \\
\hline Protein & $94.21 \pm 5.11$ & $58.82 \pm 4.11$ \\
Glucose & $138.52 \pm 32.82$ & $130.78 \pm 4.97$ \\
Tiacyloglicerols & $999.18 \pm 68.67$ & $1,056.23 \pm 70.98$ \\
Total cholesterol & $316.21 \pm 21.12$ & $224.09 \pm 15.48$ \\
HDL-cholesterol & $177.28 \pm 21.42$ & $203.35 \pm 16.04$ \\
\hline
\end{tabular}

w.w. wet weight 
divided into four types: I, tube foot waving; II, $\operatorname{arm}(\mathrm{s})$ movement; III, locomotion; IV, stomach bulging/eversion.

The limpets, $N$. concinna, were divided into two groups, smaller than $10 \mathrm{~mm}($ mean $=8.3, \mathrm{SD}=1.3 \mathrm{~mm})$ and larger than $10 \mathrm{~mm} \quad($ mean $=35.3, \quad \mathrm{SD}=4.2 \mathrm{~mm})$. Behavioral observations were carried out on individual limpets placed in separate small aquaria (ca. 1.5 1). Animals were left there for $15 \mathrm{~min}$, allowing them to reaffix themselves. After this time, the limpets were exposed to potential stimuli released from a syringe placed ca. $1 \mathrm{~cm}$ in front of the animal. Limpet behavior was monitored for $5 \mathrm{~min}$ and their behavioral responses were observed. Behavioral responses were divided into 4 types: I, pallial tentacles waving; II, turning around; III, sticking head outside the blood plume; IV, moving outside the blood plume.

Amphipods $W$. obesa (body length $10 \mathrm{~mm}$ ) were placed individually in 1.01 tanks $(14 \times 12 \mathrm{~cm})$ with static water and left there for 10 min to allow them to recover from handling stress. After that time, animals were found swimming freely ( $60 \%$ of tested individuals) or sitting immobile $(40 \%$ of tested individuals) on the aquarium bottom. Two crossing lines were drawn on the tank bottom dividing it into four equal zones (quadrants) (Fig. 1). Amphipod behavioral response was measured by slowly releasing one drop of potential stimulus from a syringe, slightly immersed in seawater, into one of the four zones of the aquarium. Animals were then filmed for 5 min with a digital video camera and the time spent in each zone was subsequently measured.

Nemerteans $P$. corrugatus (relaxed body length 50$60 \mathrm{~cm}$ ) were placed individually in 20-1 tanks with static water and left there for $1 \mathrm{~h}$ to allow them to recover from handling stress. Their behavioral response to fish blood was measured by releasing $1 \mathrm{ml}$ of potential stimulus from a syringe kept about $3 \mathrm{~cm}$ from the anterior part of the animal's body. Nemerteans were then observed for $10 \mathrm{~min}$. Changes in their behavior (head and proboscis movements),

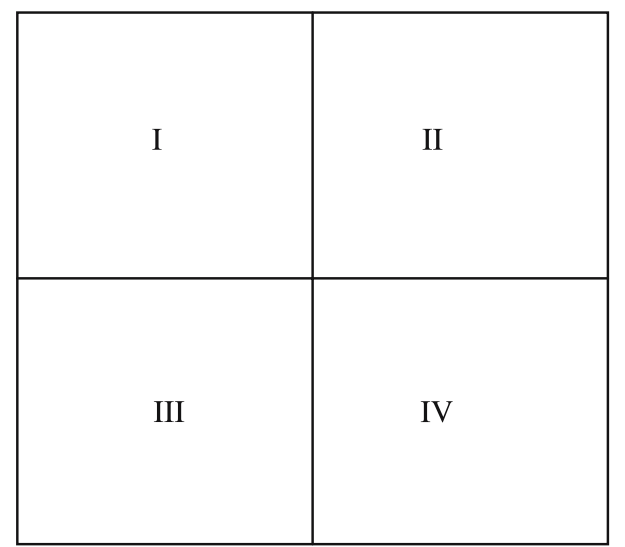

Fig. 1 Experimental design used in the observations of W. obesa reaction to blood stimuli with the aquarium bottom divided into four parts: I, II, III and IV and time spent in the zone where fish blood was released, were noted.

Sea stars $O$. validus and Lysasterias sp., and amphipod W. obesa, were tested with the blood of fish 1; the other species with the blood of fish 2 .

Data analysis was performed using the statistical package Statistica 5.5 (StatSoft, Inc.). Differences in the lengths of time spent by amphipods in different zones of the aquarium were compared using ANOVA and RIR Tukey test after first checking that data distribution was normal. Differences in the mean number of reaction types displayed simultaneously by sea stars $O$. validus were compared using Student's $t$ test after first checking that data distribution was normal.

\section{Results}

O. validus and Lysasterias sp. showed no behavioral response to pure seawater, but both species reacted positively to fish blood (Table 2). The reaction of $O$. validus consisted of tube foot waving, arms movements, locomotion, and stomach eversion. Animals displaying locomotion moved towards the stimulus source. As much as $60 \%$ of sea stars displayed all four types of reactions simultaneously. Mean number of reaction types displayed simultaneously by $O$. validus was $3.3(\mathrm{SD}=0.47)$ (Table 2$)$. No stomach eversions were observed in Lysasterias sp. exposed to fish blood. Sea stars belonging to this species reacted by tube foot waving, arm movements and locomotion. Animals displaying locomotion moved towards the stimulus source. Mean number of reaction types displayed simultaneously was significantly lower (Student's $t$ test, $P<0.001$ ) than in O. validus. As much as $40 \%$ of sea stars displayed all three types of reactions simultaneously.

The amphipods $W$. obesa reacted to pure seawater released slowly from the syringe by swimming through all zones of the aquarium (Table 3 ). No significant differences were found between times spent by amphipods in different zones of the aquarium after the seawater treatment (ANOVA, $F_{(N=76,3)}=0.385, P=0.763$ ). Fish blood also caused swimming activity in amphipods, but animals spent most of the time near the place where the blood was released $(239.4 \mathrm{~s})$ in comparison to $20.1 \mathrm{~s}$ spent in any other zone. Significant differences were found between times spent by amphipods in different zones of the aquarium $\left(\right.$ ANOVA, $\left.F_{(N=76,3)}=1,489.97, P<0.001\right)$. Statistically significant differences were observed between time spent by amphipods in the zone where fish blood was released and other zones (Tukey HSD test, $P<0.05$ ).

As only three specimens of $P$. corrugatus were tested, the results cannot be treated as conclusive. No reaction to pure seawater was observed, but all specimens reacted strongly to fish blood released slowly near their anterior end. Same 
Table 2 Behavioral responses of sea stars O. validus and Lysasterias sp. to fish blood

\begin{tabular}{|c|c|c|c|c|c|c|c|c|c|}
\hline \multirow{2}{*}{$\begin{array}{l}\text { Sea star } \\
\text { species }\end{array}$} & \multirow{2}{*}{$\begin{array}{l}\text { Stimulus } \\
\text { type }\end{array}$} & \multirow{2}{*}{$\begin{array}{l}\text { Animals } \\
\text { tested }\end{array}$} & \multicolumn{4}{|c|}{ Positive responses (\%) } & \multirow{2}{*}{$\begin{array}{l}\text { Negative } \\
\text { responses (\%) }\end{array}$} & \multicolumn{2}{|c|}{ No. of reaction types/animal } \\
\hline & & & I & II & III & IV & & Mean & SD \\
\hline \multirow[t]{2}{*}{ O. validus } & Control & 20 & 0 & 0 & 0 & 0 & 100 & - & - \\
\hline & Blood & 20 & 100 & 100 & 50 & 70 & 0 & 3.3 & 0.47 \\
\hline \multirow[t]{2}{*}{ Lysasterias sp. } & Control & 20 & 0 & 0 & 0 & 0 & 100 & - & - \\
\hline & Blood & 20 & 100 & 100 & 40 & 0 & 0 & 2.4 & 0.50 \\
\hline
\end{tabular}

Positive behavioral responses are divided into types: I, tube foot waving; II, arm(s) movement; III, locomotion; IV, stomach bulging or eversion Control: pure seawater

Table 3 The impact of fish blood on time(s) spent by W. obesa in each of the four zones of the experimental aquarium

\begin{tabular}{|c|c|c|c|c|c|c|c|c|c|}
\hline \multirow{2}{*}{$\begin{array}{l}\text { Stimulus } \\
\text { type }\end{array}$} & \multirow{2}{*}{$\begin{array}{l}\text { Animals } \\
\text { tested }\end{array}$} & \multicolumn{2}{|l|}{ Zone I } & \multicolumn{2}{|c|}{ Zone II } & \multicolumn{2}{|c|}{ Zone III } & \multicolumn{2}{|c|}{ Zone IV } \\
\hline & & Mean & SD & Mean & $\mathrm{SD}$ & Mean & SD & Mean & SD \\
\hline Seawater & 20 & 70.0 & 33.8 & 78.4 & 34.4 & 72.4 & 26.1 & 79.2 & 34.8 \\
\hline Blood & 20 & 239.4 & 20.9 & 21.5 & 9.8 & 19.7 & 7.8 & 19.1 & 7.1 \\
\hline
\end{tabular}

Control experiment: pure seawater released in zone I; blood experiment: fish blood released in zone I

behaviors were observed in all the three individuals (extended proboscis, lifting of the anterior part of the body, oscillating movements of the proboscis and anterior part of the body). Animals moved slowly about, but only within the borders of blood plume. In one instance, a small blood clot was found and ingested by one of the nemerteans.

The limpet $N$. concinna showed virtually no behavioral reaction to pure seawater, and sat immobile on the aquarium bottom with pallial tentacles extended outside their shells (Table 4). None of the individuals larger than $10 \mathrm{~mm}$ responded to the blood stimuli. All limpets from this group stayed without any movement in the same place. Most (95\%) of the individuals from the group smaller than $10 \mathrm{~mm}$ displayed active behavioral reaction to the blood stimuli. After $20 \mathrm{~s}$ (mean, $\mathrm{SD}=5.2 \mathrm{~s}$ ), limpets started to wave pallial tentacles, turned around, took up position with their heads outside the blood plume and moved away from the plume with a speed of $2-7 \mathrm{~mm} / 10 \mathrm{~s}(80 \%)$, which was their normal walking speed during the feeding. Distance covered by the limpets' move was $3-5 \mathrm{~cm}$.

\section{Discussion}

All necrophagous macroinvertebrates showed strong behavioral reactions to blood stimulus. Such responses were previously observed in other species belonging to different taxa. Blood sera and mucus from a range of teleost fishes were found to be effective attractants for the theronts of the parasitic ciliate Ichthyophthirius multifiliis (Buchmann and Nielsen 1999). Gurin and Carr (1971) observed that the marine snails Nassarius obsoletus, a deposit feeder and a facultative carrion feeder, reacted strongly by extending their proboscises not only to a variety of substances arising from dead animals but also to human plasma and serum. Authors speculate that blood proteins, especially albumins and globulins. may be biologically active in attracting predators and scavengers. Proteins have also been previously shown to attract crustaceans, molluscs and echinoderms (Carr et al. 1974; Rittschof et al. 1984; Carr 1988). Glucose was also established to be an important attractant to such diverse species

Table 4 Behavioral responses of limpet $N$. concinna to fish blood

\begin{tabular}{|c|c|c|c|c|c|c|c|}
\hline \multirow{2}{*}{$\begin{array}{l}\text { Animal } \\
\text { size }\end{array}$} & \multirow{2}{*}{$\begin{array}{l}\text { Stimulus } \\
\text { type }\end{array}$} & \multirow{2}{*}{$\begin{array}{l}\text { Animals } \\
\text { tested }\end{array}$} & \multicolumn{4}{|c|}{ Positive responses (\%) } & \multirow{2}{*}{$\begin{array}{l}\text { Negative } \\
\text { responses }(\%)\end{array}$} \\
\hline & & & $\mathrm{I}$ & II & III & IV & \\
\hline \multirow[t]{2}{*}{ Large } & Seawater & 20 & 0 & 0 & 0 & 0 & 100 \\
\hline & Blood & 20 & 0 & 0 & 0 & 0 & 100 \\
\hline \multirow[t]{2}{*}{ Small } & Seawater & 20 & 0 & 0 & 0 & 0 & 100 \\
\hline & Blood & 20 & 95 & 95 & 30 & 65 & 5 \\
\hline
\end{tabular}

Positive behavioral responses are divided into types: I, waving pallial tentacles; II, turning around; III, sticking head outside the blood plume; IV, moving outside the blood plume

Control, pure seawater; small size, limpets with shell length shorter than $10 \mathrm{~mm}$; large size, limpets with shells length longer than $10 \mathrm{~mm}$ 
as Antarctic sea urchin Sterechinus neumayeri (Janecki 1999), gastropod Lymnea acuminata (Tiwari and Singh 2004) or crabs Petrolisthes cinctipes (Hartman and Hartmann 1977) and Uca longisignalis (Weissburg and ZimmerFaust 1991). Therefore, it can be assumed that the same chemical compounds (proteins, glucose) found in Notothenia blood were also used as attractants by Antarctic scavenging invertebrates, although further studies are needed to determine the impact of respective blood constituents on the scavenger's behavior.

Terrestrial animals also respond to the smell of blood. Brown treesnakes (Boiga irregularis) reacted with tongue flicks to mammalian blood and blood serum (from rabbits, rats, and mice) (Chiszar et al. 2001). Dry bovine blood was an olfactory attractant for the screwworm fly Cochliomyia hominivorax (Hammack et al. 1989) and the antennae and maxillary palps of the fleshfly, Neobellieria bullata, were shown to be sensitive to a mixed cow and pig blood extract (Wasserman and Itagaki 2003).

It was also observed that hermit crabs with too small or badly fitting shells, readily responded to odours, signaling potential shell availability, originating from dying gastropods or dying hermit crabs-chemical cues from hermit crabs were found in their hemolymph (Rittschof et al. 1992, 1995; Thacker 1994).

Blood odour may also perform the function of an alarm signal for some animals. It has been demonstrated that rats avoided the odour of blood from other rats (Mackay-Sim and Laing 1981). Changes in behavior were also observed in cattle exposed to the smell of blood from their conspecifics (Terlow et al. 1998). Many aquatic invertebrate species were observed to display alarm or flight in response to chemical cues emanating from dead or injured conspecifics. Echinoderms such as Asterias rubens, Psammechinus miliaris and Echinus esculentus moved away from homogenates of conspecific interior tissues (Cambpell et al. 2001). Aquatic flatworms, Dugesia dorotocephala, used chemical signals fron injured conspecifics to evaluate predation risk (Wisenden and Millard 2001). Chemical compounds released from crushed conspecifics inhibited feeding in pebble crabs Philyra laevis (McKillup and McKillup 1992), gastropods Nassarius siquijorensis (Morton and Chan 1999), and hard clams Mercenaria mercenaria (Smee and Weissburg 2006).

The presence of blood (or hemolymph) components in the environment is a signal informing nearby organisms about the predation event or its consequences (e.g., remains of a predator's meal or an injured animal susceptible to further attacks). Such knowledge may be important especially for necrophagous and kleptoparasitic species whose food supply is partially dependent on successful predators. Their ability to exploit such events can be discerned from the observations of amphipod swarms attacking slightly injured
Antarctic fish that were immobilised in fishing nests (Kidawa, personal observations).

The difference in the reaction of small and large limpets observed in our experiments was typical for many other invertebrate species with small and/or young individuals distancing themselves from the immediate vicinity of a predation event (e.g., Vadas et al. 1994; Wahle 1992; Sparrevik and Leonardsson 1995). Such data show that small individuals, being less mobile and more susceptible to predation, show distinct differences in the way they interact with their environment and react to chemical signals. Small limpets' sensitivity to blood components enables them to avoid sea stars congregating on bloody remains.

Chemical cues, released from dead or injured prey, are dispersed in the marine environment by water currents, and are diluted proportionally to the distance from their source. Many marine organisms can detect chemical compounds even at low concentrations from $10^{-8}$ to $10^{-10} \mathrm{~g} \mathrm{l}^{-1}$ (e.g. Zimmer-Faust and Case 1983; Rebach et al. 1990), but their response depends strongly on stimulus concentration, with its rise causing an increase in both the percentage of reacting individuals and the strength of their reaction (e.g. Zimmer-Faust and Case 1983; McClintock et al. 1984; Kidawa 2005b). Signal concentration can be used by organisms as an information about both the distance to the food item and its size (Sainte-Marie and Hargrave 1987). Intense chemical cues can be used in the laboratory to elicit a maximum reaction from the tested individuals, although further studies are needed to observe the whole range of possible behavioral changes. In natural conditions, even slow moving organisms (whelks Buccinum undatum) can travel long distances following cues transported by water currents (Himmelman 1988; Lapointe and Sainte-Marie 1992). Field observations in the Antarctic showed that scavenging species (sea star O. validus, gastropod Neobuccinum eatoni and nemertean $P$. corrugatus) reached the bait only after 3 days, implicating their ability to cover long distances in reaction to probably much diluted signals (Zamorano et al. 1986).

Notothenioid fish are preyed upon by almost all Antarctic top predators such as south pole skuas, Antarctic petrels, Adélie and emperor penguins, Weddell seals and minke, and killer whales (La Mesa et al. 2004). We did not find data in the literature on the rate of predation success, although there are reports showing that Weddell seals discard prey remains (skin and tail of Antarctic cod Dissostichus mawsoni) on the sea bottom (Slattery and Oliver 1986). Data on predatory success in double-crested cormorants (Phalacrocorax auritus) from British Columbia (Canada) showed that approximately half of the prey pursuits initiated by cormorants did not lead to prey capture, although with small prey items (24-92 g), less than $1 \%$ of pursued fish were injured without being ingested (Grémillet 
et al. 2006). This study also indicates that rate of prey loss (and potential injury) increases with fish size, leaving more injured prey for secondary predators and necrophagous species.

Other predatory events, such as leopard seals catching penguins or seals, may also leave prey remains or severely injured prey in its aftermath. Penney and Lowry (1967) observed that leopard seals can effectively catch a penguin only by using stealth: a wait and rush tactic. They kill the bird by grabbing its feet, shaking it vigorously and beating its body against the surface of the water repeatedly until the penguin is dead and skinned. It may be assumed that such a way of killing leaves a considerable amount of blood in the water but also a lot of small pieces of prey body sinking to the bottom. All three necrophagous species examined in our study are known to react strongly to chemical signals. $O$. validus was previously shown to use chemical cues to locate food source (Kidawa 2005a), and to react to chemical signals produced by its conspecifics (Kidawa 2001). Amphipod W. obesa was found to respond to several amino acids by a strong increase in its metabolic rate (Janecki and Rakusa-Suszczewski 2005). Such an increase was noticed earlier in animals belonging to different species (e.g., Smith and Baldwin 1982; Shumway et al. 1993; Kidawa 2005a, b), and is part of a strategy that enables animals to survive under low and unpredictable food conditions, with rapid increase in metabolic rate in response to a chemical signal being a preparation for the increased locomotory activity needed for food finding (Smith and Baldwin 1982). P. corrugatus was also observed to forage using chemoreception (Dayton, unpublished, in McDermott and Roe 1985). All three species were caught in baited traps (Presler 1986) and were obseved forming feeding aggregations (Dayton et al. 1974; Zamorano et al. 1986; Markowska personal observation). The ability to detect blood components and use them as a source of information in detecting food sources has a clear adaptive value for Antarctic marine scavengers, enabling them to widen their food spectrum and increasing their chances of survival.

Acknowledgments Data presented in this study were collected during the XXIX Polish Antarctic Expedition at H. Arctowski Station (King George Island, South Shetlands). The work was financed by the State Committee for Scientific Research grant 3 P04F 02325 (years 2003-2006). Particular thanks are addressed to three anonymous referees for their most helpful comments on the manuscript.

\section{References}

Arnaud PM (1970) Frequency and ecological significance of necrophagy among the benthic species of Antarctic coastal waters. In: Holdgate MW (ed) Antarctic ecology, vol 1. Academic, London, pp 259-267
Berne S, Sepči K, Križaj I, Kem W, McClintock JB, Turk T (2003) Isolation and characterisation of a cytolytic protein from mucus of the Antarctic heteronemertine Parborlasia corrugatus. Toxicon 41:483-491

Buchmann K, Nielsen ME (1999) Chemoattraction of Ichthyophthirius multifiliis (Ciliophora) theronts to host molecules. Int J Parasitol 29:1415-1423

Campbell AC, Coppard S, D'Abreo C, Tudor-Thomas R (2001) Escape and aggregation responses of three echinoderms to conspecific stimuli. Biol Bull 201:175-185

Carr WES (1988) The molecular nature of chemical stimuli in the aquatic environment. In: Atema J, Fay RR, Popper AN, Tavolga WN (eds) Sensory biology of aquatic animals. Springer, New York, pp 3-27

Carr WES, Hall ER, Gurin S (1974) Chemoreception and the role of proteins: a comparative study. Comp Biochem Physiol A 47:559566

Chiszar D, Dunn TM, Stark P, Smith HM (2001) Response of brown treesnakes (Boiga irregularis) to mammalian blood: whole blood, serum, and cellular residue. J Chem Ecol 27:979-984

Clarke A (1983) Life in cold water: the physiological ecology of polar marine ectotherms. Oceanogr Mar Biol A Rev 21:341-353

Clarke A (1988) Seasonality in the Antarctic marine environment. Comp Biochem Physiol B 90:461-473

Clarke A, Leakey RJG (1996) The seasonal cycle of phytoplanton, macronutrients and the microbial community in a nearshore Antarctic marine ecosystem. Limnol Oceanogr 41:1281-1294

Davenport J (1997) Comparisons of the biology of the intertidal subantarctic limpets Nacella concinna and Kerguelenella lateralis. J Molluscan Stud 63:39-48

Dayton PK, Robilliard GA, Paine RT, Dayton LB (1974) Biological accomodation in the benthic community at McMurdo Sound, Antarctica. Ecol Monogr 44:105-128

Dearborn JH (1977) Food and feeding characteristics of Antarctic asteroids and ophiuroids. In: Llano GA (ed) Adaptation within Antarctic ecosystems. Gulf Publishing, Houston, pp 293-326

Dudgeon D, Cheung PS (1990) Selection of gastropod prey by a freshwater crab. J Zool (Lond) 220:147-155

Graeve M, Dauby P, Scailteur Y (2001) Combined lipid, fatty acid and digestive tract content analyses: a penetrating approach to estimate feeding modes of Antarctic amphipods. Polar Biol 24:853862

Grémillet D, Enstipp RE, Boudiffa M, Liu H (2006) Do cormorants injure fish without eating them? A underwater video study. Mar Biol 148:1081-1087

Gurin S, Carr WE (1971) Chemoreception in Nassarius obsoletus: the role of specific stimulatory proteins. Science 174:293-295

Hammack L, Pomonis JG, Flath RA, Hakk H (1989) Multicomponent attractant for female screwworm flies, Cochliomyia hominivorax, in bovine blood. J Chem Ecol 15:25-36

Hartman BH, Hartman MS (1977) The stimulation of filter feeding in the porcelain crab Petrolithes cinctipes Randall by amino acids and sugars. Comp Biochem Physiol A 56:19-22

Heine JN, McClintock JB, Slattery M, Weston J (1991) Energetic composition, biomass and chemical defense in the common Antarctic nemertean Parborlasia corrugatus McIntosh. J Exp Mar Biol Ecol 153:15-25

Himmelman JH (1988) Movement of whelks (Buccinum undatum) towards a baited trap. Mar Biol 97: 521-531

Janecki T (1999) Reaction of Antarctic sea urchins, Sterechinus neumayeri (Echinodermata: Echinoidea) to glutamic acid and glucose. Pol Arch Hydrobiol 46:325-330

Janecki T, Rakusa-Suszczewski S (2005) The influence of starvation and amino acids on metabolism of the Antarctic amphipod Waldeckia obesa. J Crust Biol 25:196-202 
Jørgensen LL (2005) Impact scenario for an introduced decapod on Arctic epibenthic communities. Biol Invasions 7:949-957

Kidawa A (2001) Antarctic starfish, Odontaster validus, distinguish between fed and starved conspecifics. Polar Biol 24:408-410

Kidawa A (2005a) The role of amino acids in phagostimulation in the shallow-water omnivorous Antarctic sea star Odontaster validus. Polar Biol 28:147-155

Kidawa A (2005b) Behavioural and metabolic responses of the Antarctic sea star Odontaster validus to food stimuli of different concentration. Polar Biol 28:449-455

La Mesa M, Eastman JT, Vacchi M (2004) The role of notothenid fish in the food web of the Ross Sea shelf waters: a review. Polar Biol 27:321-338

Lapointe V, Sainte-Marie B (1992) Currents, predators and the aggregations of the gastropod Buccinum undatum around bait. Mar Ecol Prog Ser 85:245-257

Mackay-Sim A, Laing D (1981) Rats' responses to blood and body odors of stressed and nonstressed conspecifics. Physiol Behav 27:503-510

McClintock JB (1994) The trophic biology of antarctic echinoderms. Mar Ecol Prog Ser 111:191-202

McClintock JB, Klinger TS, Lawrence JM (1984) Chemoreception in Luidia clathrata (Echinodermata: Asteroida): qualitative and quantitative aspects of chemotactic responses to low molecular weight compounds. Mar Biol 84:47-52

McClintock JB, Pearse JS, Bosch I (1988) Population structure and energetics of the shallow-water antarctic sea star Odontaster validus in contrasting habitats. Mar Biol 99:235-246

McDermott JJ, Roe P (1985) Food, feeding behaviour and feeding ecology of nemerteans. Am Zool 25:113-125

McKillup SC, McKillup RV (1992) Inhibition of feeding in response to crushed conspecifics by the pebble crab Philyra laevis (Bell). J Exp Mar Biol Ecol 161:33-43

Morton B, Chan K (1999) Hunger rapidly overrides the risk of predation in the subtidal scavenger Nassarius siquijorensis (Gastropoda: Nassariidae): an energy budget and a comparison with the intertidal Nassarius festvus in Hong Kong. J Exp Mar Biol Ecol 240:213-228

Penney RI, Lowry G (1967) Leopard seal predation on Adelié penguins. Ecology 48:878-882

Petersen CH, Skilleter GA (1994) Control of foraging behavior of individuals within an ecosystem context: the clam Macoma balthica, flow environment, and siphon-cropping fishes. Oecologia 100:256-267

Picken GB (1980) The distribution, growth and reproduction of the Antarctic limpet Nacella (Patinigera) concinna (Strebel 1908). J Exp Mar Biol Ecol 42:71-85

Presler P (1986) Necrophagous invertebrates of the Admiralty Bay of King George Island (South Shetland Islands, Antarctica). Pol Polar Res 7:25-61

Rebach S, French DP, von Staden FC, Wilber MB, Byrd VE (1990) Antennular sensitivity of the rock crab Cancer irroratus to food substances. J Crust Biol 10:213-217

Rittschof D, Shepherd R, Williams LG (1984) Concentration and preliminary characterization of a chemical attractant of the oyster drill, Urosalpinx cinerea. J Chem Ecol 10:63-79

Rittschof D, Tsai DW, Massey PG, Blanco L, Kueber GL Jr, Haas RJ (1992) Chemical mediation of behavior in hermit crabs: alarm and aggregation cues. J Chem Ecol 18:959-984
Rittschof D, Sarrica J, Rubenstein D (1995) Shell dynamics and microhabitat selecyion by striped legged crabs, Clibanarius vittatus (Bosc). J Exp Mar Biol Ecol 192:157-172

Saine-Marie B, Hargrave BT (1987) Estimation of scavenger abundance and distance of attraction to bait. Mar Biol 94:431-443

Shumway SE, Lesser MP, Crisp DJ (1993) Specific dynamic action in the herbivorous marine periwinkles, Littorina Littorea $\mathrm{L}$ and Littorina obtusata L (Mollusca, Gastropoda). Comp Biochem Physiol 106A:391-395

Slattery PN, Oliver JS (1986) Scavenging and other feeding habits of lysianassid amphipods (Orchomene spp.) from McMurdo Sound, Antarctica. Polar Biol 6:171-177

Smee DL, Weissburg MJ (2006) Hard clams (Mercenaria mercenaria) evaluate predation risk using chemical signals from predators and injured conspecifics. J Chem Ecol 32:605-619

Smith KL Jr, Baldwin RJ (1982) Scavenging deep-sea amphipods: effects of food odor on oxygen consumption and proposed metabolic strategy. Mar Biol 68:287-298

Sparrevik E, Leonardsson K (1995) Effects of large Saduria entomon (Isopoda) on spatial distribution of their small $S$ entomon and Monoporeia affinis (Amphipoda) prey. Oecologia 101:177-184

Terlouw EMC, Boissy A, Blinet P (1998) Behavioural responses of cattle to the odours of blood and urine from conspecifics and to the odour of faeces from carnivores. App Anim Behav Sci 57:921

Thacker RW (1994) Volatile shell-investigation cues of land hermit crabs: effect of shell fit, detection of cues from other hermit crab species, and cue isolation. J Chem Ecol 20:1457-1482

Tiwari F, Singh DK (2004) Behavioural responses of the snail Lymnaea acuminata to carbohydrates in snail-attractant pellets. Naturwissenschaften 91:378-380

Vadas RL, Burrows MT, Hughes RN (1994) Foraging strategies of dogwhelks, Nucella lapillus (L): interacting effects of age, diet and chemical cues to the threat of predators. Oecologia 100:439 450

Wahle RA (1992) Body-size dependent anti-predator mechanisms of the American lobster. Oikos 65:52-60

Wasserman SL, Itagaki H (2003) The olfactory responses of the antenna and maxillary palp of the fleshfly, Neobrllieria bullata (Diptera: Sarcophagidae), and their sensitivity to blockage of nitric synthase. J Insect Physiol 49:271-280

Weissburg MJ, Zimmer-Faust RK (1991) Ontogeny versus phylogeny in determining patterns of chemoreception: initial studies with fiddler crabs. Biol Bull 181:205-215

Wisenden BD, Millard MC (2001) Aquatic flatworms use chemical cues from injured conspecifics to assess predation risk and to associate risk with novel cues. Anim Behav 62:761-766

Zajac RN (1995) Sublethal predation on Polydora cornuta (Polychaeta: Spinidea): patterns of tissue loss in a field population, predator functional response and potential demographic impacts. Mar Biol 123:531-541

Zamorano JH, Duarte WE, Moreno CA (1986) Predation upon Laternula elliptica (Bivalvia, Anatinidae): a field manipulation in South Bay, Antarctica. Polar Biol 6:139-143

Zimmer RK, Butman CA (2000) Chemical signaling processes in the marine environment. Biol Bull 198:167-187

Zimmer-Faust RK, Case JF (1983) A proposed dual role of odor in foraging by the California spiny lobster, Panulirus interruptus (Randall). Biol Bull 164:341-353 